\title{
カルボン酸末端を持つスチリル型オキサゾリンマクロモノマーの 合成とその酵素担体としての応用
}

\author{
宮本 真敏*1 ・岡田 寿夫*2 ・ 中 建介*3 $・$ 三枝 武夫*4
}

(受付 1992 年 5 月 6 日・蕃查終了1 1992 年 5 月 8 日)

\begin{abstract}
要 旨 2-メチル-2-オキサソリン及び2-エチル-2-オキサソリンのカチオン開理重合のリビング性を利用し, 開始 末端にスチリル基を有し、生長末端にカルボン酸基有するマクロモ/マー（4)を新たに合成した．スチリル基及ひ

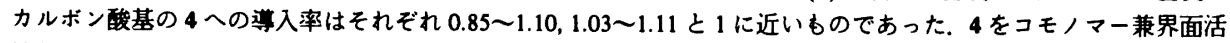
性郕として用いるスチレンとのンープフリー乳化共重合を行うことにより，カルボン酸基を表面に効率的に萑入し

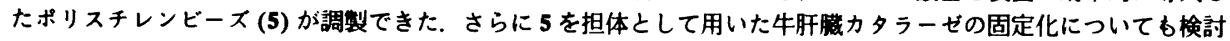
を加えた.
\end{abstract}

\section{1 緒言}

2-オキサソリン類 (1) のカチオン開環重合はリビング 的に進行するため, その開始末端，あるいは生長末端へ の官能基の導入は容易であり，すでに 1 より誘導された 数多くのマクロモ/マー，テレケリックポリマーの合成 が報告されている゙市）．また1の重合体であるポリ $[(N$ アシルイミノ)エチレン] (2)はその繰り返し単位のアミ 卜基に由来する高い両親媒性一親水性加つ親油性一を示 し, 帯電防止剂, 界面活性剂, ヒドロゲルなどにその特 性を応用した研究が報告されている6 田，さらに開始末 端にスチリル基を有するマクロモノマー(3)のスチレ ン,メタクリル酸メチルとの乳化共重合はそれ自体の界 面活性能のためにンープフリーで行えることも最近報告 されているか，これは 2 の両親媒性と官能基の導入の容 易さをともに生かした研究(例である ${ }^{12), 13) . ~}$<smiles>[R]C1=NCCO1</smiles>

1

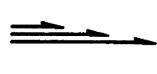

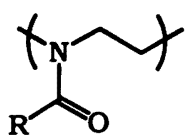

2
筆者らは 2 のこれらの特性を生かし，すでにカタラー ゼが末端にカルボン酸基を有する 2 で化学修飾すること により, ベンゼン, クロロホルムなどの有機溶媒に可溶

*1 富山大学工学部化学生物工学科（E930 富山市五福 3190)

* 京都大学工学部合成化学科（⑥06 京都市左京区吉田本町）

*3 鹿児島大学工学部応用化学科（正890 鹿児島市郡元 1-2140)

*4 西新技術研究所（\$600 京都市下京区中堂寺南町 17）
化し，かつ，有機溶媒中で高い触媒活性を示すことを報 告している(4)．この場合 2 は親油性基として触媒の有機

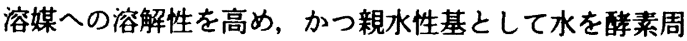
囲に保持して醭素の高次構造の变化を抑制しているもの と推測している.このような有機溶媒中で活性な醭素の 固定化は工業的見地から非常に興味深いあのである. 本 報文では 2 の開始末端にスチリル基を，また生長末端に カルボン酸基を導入した末端反応性マクロモノマー (4) を新規に合成しこれとスチレンとのッープフリー乳化 共重合を行い，カルボン酸を表面に有するポリスチレン ビーズ(5)を調製した。 さらにこれを担体として用いた カタラーゼの固定化を検討したので以下に報告する.

\section{2 実}

\section{1 試料}

2-メチル-2-オキサソリン (1a) 及び2-エチル-2-オキサ ゾリン (1b) は Aldrich Chemical 社 より購入したものを 水酸化カリウム上で乾燥後, 窒素下蒸溜した後に使用し た. クロロメチルスチレン $\left(p^{-}, m^{-}\right.$混合物) は市眅のも のをヒドロキノンモノェチルエーテルの存在下減圧蒸溜 した後に使用した。 グルタル酸はクロロホルムから再結 晶した後に用いた。牛肝㼨カタラーゼ $\left(\mathrm{H}_{2} \mathrm{O}_{2}: \mathrm{H}_{2} \mathrm{O}_{2} \mathrm{Ox}\right.$ idoreductase; EC 1.11.1.6) は Sigma Chemical 社より睡入 したものを既報のとおりに精製した後に使用した ${ }^{14)}$ ，溶 媒類、スチレン、ジビニルベンゼン，及び 2,6-ルチジン は常法に従って乾燥後, 窒素下蒸留したものを使用し た。

\section{2 装置}

$60 \mathrm{MHz}{ }^{1} \mathrm{H}$ NMR スペクトルは日立 R-600 型核磁気共 鳴装置を, IR スペクトルはパーキンェルマーFT-IR 
宮本・岡田・中・三枝

1640 型分光光度計を, 柴外線吸収スペクトルは日立 200-20 型分光光度計をそれぞれ用いて測定した．マクロ モノマーの分子量は别途合成した分子量既知の $2\left(M_{w} /\right.$ $M_{n} \sim 1.1$ ) を標準試料に用いて GPC (TSK-Gel G2500 $\mathrm{HX}_{\mathrm{L}}$ カラム, クロロホルム）により決定した。

$2.3 a$-スチリルメチル-正-(3-カルボキシプロピルオキ シカルボニル)ポリ [(N-アシルイミノ)エチレン $]$

(4) の合成

代表的な例を以下に記す．あらかじめ乾燥させたヨウ 化カリゥム $0.270 \mathrm{~g}(1.80 \mathrm{mmol})$ とヒドロキノンモノメ チルエーテル $0.01 \mathrm{~g}$ とを三方コック付きの還流冷却器 を付け磁気筧拌子を入れたナスフラスコ中に取り，さら に真空下で 30 分間乾燥後窒素置換をした，窒素下で $3.53 \mathrm{~g}(41.4 \mathrm{mmol})$ の 1a，アセトニトリル $18 \mathrm{ml}$ を加え， 水冷した後にクロロメチルスチレン $0.148 \mathrm{~g}(0.970$ $\mathrm{mmol})$ を加えた。混合液を $70^{\circ} \mathrm{C} て ゙ 24$ 時間反応させた 後, 全量 $21 \mathrm{~m} l$ の反応溶液のうちの $1 \mathrm{ml}$ を取り, ジェチ ルエーテル/ヘキサン 1:1 混合液に加え，スチリル末端 を持つマクロモノマー(3) を沈殿させた。 さらにこれを 塩化メチレンに溶かし，乃過して不溶性の塩（ヨウ化ナ トリゥム及び塩化ナトリウム）を除いたのちにジェチル エーテル/ヘキサン $1: 1$ 混合液からの再沈殿により 3 の 精製を行った. 真空乾燥後 $0.12 \mathrm{~g}$ の淡黄色粉末状の 3 を 得た。

残部の重合反応溶液はグルタル酸 $1.28 \mathrm{~g}(9.69 \mathrm{mmol})$ とアセトニトリル $5.6 \mathrm{ml}$ と 2,6-ルチジン $3.12 \mathrm{~g}(29.1$ $\mathrm{mmol})$ との混合液を窒素下で加え, $70^{\circ} \mathrm{C}$ でさらに 16 時 間反応させた，反応液をジェチルエーテル/ヘキサン 1 : 1 混合液に加え，ポリマー(4) を沈殿させたのちに， 上 ドロキノンモノメチルエーテルを $0.1 \%$ 含むメタノール に溶解させ、ゲルろ過 (Sephadex LH-60) により塩類及 び過剩のグルタル酸とルチジンを除いた．4を含むメ夕 ノールフラクションにアンバーリスト15（H 型） $3 \mathrm{~g} を$

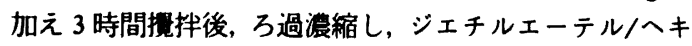
サン混合液からの再沈殿を行い, 4 を単離し, 再沈殿 (塩 化メチレン溶媒）を絽り返して精製した，真空乾燥後
$2.93 \mathrm{~g}$ の淡黄色粉末状の 4 を得た。

$2.4 N-(2$-ヒドロキシメチル)-N-スチリルメチルアセ トアミド(6)の合成

ヨウ化カリウム $17.5 \mathrm{~g}(117 \mathrm{mmol})$ とヒドロキノンモ ノメチルエーテル $0.6 \mathrm{~g}$ をスフラスコ中に取り, 真空 下で 30 分間乾燥後窒素置換をした。 アセトニトリル 50 $\mathrm{m} l$ とクロロメチルスチレン $8.93 \mathrm{~g}(58.5 \mathrm{mmol})$ を加え, 30 分間僄流したのち $1.00 \mathrm{~g}$ の $1 \mathrm{a}(11.7 \mathrm{mmol})$ を加え, 再び 1 時間還流した。約 $5 \mathrm{~m} l$ に濃縮したのち, $50 \mathrm{ml}$ の ジェチルエーテルを加え, 生成物を沈殿させた。 沈殿を さらに $50 \mathrm{ml}$ のジェチルエーテルで洗浄して過剩のクロ ロメチルスチレンを除いた後, 塩化メチレンに溶かし， ろ過して脱塩した。蒸発乾固後メタノールに溶かし, $7.32 \mathrm{~g}$ のアンバーライト R410 (水酸基型) を加えて 3 時 間筧拌後，ろ過濃縮した。へキサン/ベンゼン $1: 1$ 混合 液を展開媒としてシリカゲルカラムで橙色液状の6 6 を単 離した。構造は'H NMR, IR で確認した。 $\lambda_{\max }$ (メタノー ル) $=245 \mathrm{~nm}(\varepsilon=9520)$.

\section{5 勫化共重合}

反応フラスコ中に $4 \mathrm{a}$ を $0.25 \mathrm{~g}, \mathrm{pH} 3.6$ フタル酸緩衝溶 液 $45 \mathrm{ml}$ ，過硫酸カリゥム $0.2 \mathrm{~g}$ ，ジビニルベンゼン 0.1 $\mathrm{g}$ ，スチレン $5.0 \mathrm{~g}$ を加え, 窒素気流下 $70^{\circ} \mathrm{C}$ で 8 時間加熱 㩲拌した. 氷冷後ろ過により共重合体 5a を単離し, 水, ついでメタノールで洗浄し真空乾燥の後に $4.0 \mathrm{~g}$ の白色 ビーズ状の 5a を得た. 共重合体中のスチリル含量は IR より (Table 2 脚注参照), カルボン酸含量は 5 を過剩量 の $0.01 N$ 水酸化ナトリウム溶液に加え, $0.01 N$ 塩酸に よる逆滴定により決定した.

\section{6 カタラーゼの固定化}

サンプル瓶中に 5a を $112 \mathrm{mg}$ と1-エチル 3-(3-ジメチ ルアミノプロピル)カルボジィミド塩酸塩 $28.1 \mathrm{mg}$ をと り $\mathrm{pH} 4.5$ リン酸緩衝液 $10 \mathrm{~m} l$ を加えた。超音波を 5 分 間照射した後にカタラーゼの $\mathrm{pH} 7.0$ リン酸緩衙液溶液 $(9.5 \mu \mathrm{M}) 2 \mathrm{ml}$ を加え, $25^{\circ} \mathrm{C}$ で 13 時間振とうした。 万過 後水洗, 乾燥し, 固定化酵素を得た。 得られた固定化醉 素の活性測定は既報に従って行った ${ }^{14)}$.<smiles>C=Cc1ccc(CCl)cc1</smiles><smiles>[R]C1=NCCO1</smiles>

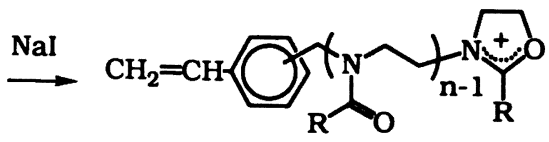

1a: $\mathrm{R}=\mathrm{Me}$ 1b; $R=E t$

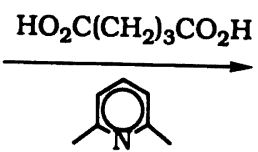<smiles>[R]C(=O)N(CCC(C)(C)OC(C)=O)Cc1ccc(C=C)cc1</smiles>

4a: $R=M e$

4b; $R=E t$ 


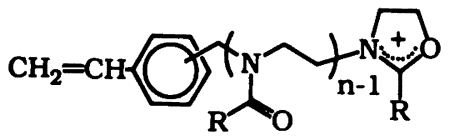

work up<smiles>[R]C(=O)N(CCCC)Cc1ccc(C=C)cc1</smiles>

3a: $R=M e$

3b; $\mathbf{R}=\mathbf{E t}$

Table 1. Preparation of $\alpha$-styrylmethyl- $\omega$-(3-carboxypropyloxycarbonyl)poly [( $N$-acylimino)-ethylene]s (4) $)$

\begin{tabular}{|c|c|c|c|c|c|c|c|c|c|}
\hline \multirow[b]{2}{*}{ Monomer } & \multirow[b]{2}{*}[\mathbf{M}]{$/[\mathrm{I}]$} & \multicolumn{2}{|c|}{ Before carboxylation } & \multicolumn{6}{|c|}{ After carboxylation } \\
\hline & & $M_{n}^{b)}$ & $M_{w} / M_{n}^{b)}$ & $\begin{array}{c}\text { Macromo- } \\
\text { nomer }\end{array}$ & $\begin{array}{l}\text { Yield } \\
(\%)\end{array}$ & $M_{n}^{b)}$ & $M_{w} / M_{n}^{b)}$ & $\begin{array}{c}F_{n}^{\mathrm{c})} \\
\text { (styryl) }\end{array}$ & $\begin{array}{c}F_{n}^{\mathrm{d})} \\
\text { (carboxyl) }\end{array}$ \\
\hline $1 \mathbf{a}$ & 42.7 & 3,700 & 1.12 & $4 a$ & 80 & 4,500 & 1.04 & 0.96 & 1.09 \\
\hline 1a & 40.0 & 3,500 & 1.08 & $3 a^{e)}$ & 95 & & & 0.93 & \\
\hline $1 \mathbf{b}$ & 22.2 & 2,200 & 1.06 & $4 b-1$ & 66 & 2,400 & 1.04 & 0.85 & 1.11 \\
\hline 1b & 42.7 & 3,500 & 1.03 & $4 \mathrm{~b}-2$ & 76 & 3,800 & 1.03 & 1.10 & 1.03 \\
\hline
\end{tabular}

a) Conditions for polymerization and carboxylation are descibed in Experimental section.

b) Determined by GPC with poly [( $N$-acylimino $)$ ethylene] standards.

c) Extent of functionalization of styryl group at the initiating end of 3 or 4: estimated from UV absorption at $245 \mathrm{~nm}$.

d) Extent of functionalization of carboxyl group at the propagating end of 4: determined by titration.

c) $\alpha$-Styrylmethyl- $\omega$-hydroxypoly [( $N$-acetylimino $)$ ethylene].

\section{3 結果及び考察}

3.1 a-スチリルメチル-正(3-カルボキシプロピルオキ シカルボニル)ポリ $[(N$-アシルイミノ)エチレン $]$ (4) の合成

我々はすでに 2 のリビング生長末端を過剩量のカルボ ン酸と 2,6-ルチジン存在下で反応させることにより官能 基の末端への導入が定量的に進むことを報告してい る”．今回はクロロメチルスチレン $(p-m$-混合物）を開 始剂として用い, ヨウ化ナトリウムの存在下で2-メチ ル-2-オキサソリン (1a), あるいは2-エチル-2-オキサソ リン (1b) を重合させたのち,グルタル酸を 2,6-ルチシ ン共存下で反応させることにより，カルボン酸末端を持 つスチリル型マクロモノマー(4)を合成した。 4 の分子 量はカタラーゼの化学修飾剤として適当な 2000 から 5000 程度になるように開始郕と 2 の仕込み比で調節し た. 重合の結果を Table 1 に示す。

重合はほぼ定量的に進行し,グルタル酸との反応を行 わない場合にはほぼ定量的にマクロモノマー3a が得ら れた. 大過剩 (約 5.6 当量) のグルタル酸と反応させたカ ルボン酸型マクロモノマー4a の単離収率の減少は再沈 殿とゲルろ過による精製時のロスによるものである。 ずれの場合も GPCによって求めたマクロモノマーの分 子量は開始剤とモノマーの仕込み比から算出される値に 近く, 㹟い分子量分布とともに重合のリビング性を示し ている．またグルタル酸を加える前に重合溶液を一部抜
き出して3型のマクロモノマーを単離したが，3に比べ て4はグルタル酸との反応により分子量がいくらか増大 しているものの分子量分布にはほとんど変化がなく，グ ルタル酸との反応の際にポリマーの 2 量体化は起こって はいないことが明白である.

ポリマー中のスチリル基の含量は別途合成したモデル 化合物 $N$-(2-ヒドロキシメチル)-N-スチリルメチルアセ

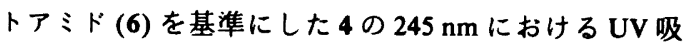

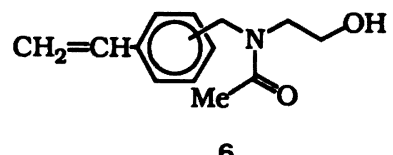

6

収強度から、また停止末端のカルボン酸基含量は $0.01 \mathrm{~N}$ 水酸化ナトリゥムによる末端基滴定から算出した。 これ と数平均分子量から算出した 2 種の官能基のポリマーへ の導入率はほぼ 1 に近く, 官能基の導入が効率良く行わ れていることが明らかとなった。

\section{2 ソープフリー勫化共重合}

機能性官能基を持つマクロモノマーを用いる共重合で は通常ポリマー表面のみに効率良く機能性官能基を導入 することは困難である. しかし，両親媒性の4自身を界 面活性剤とするンープフリー乳化共重合を行えば，特に 親水性の高いカルボン酸末端は共重合体表面に露出する あのと考えて4のスチレンとの共重合を検討した。

重合結果を Table 2 に示す. 乳化共重合は過硫酸カリ 
宮本・岡田・中・三枝

Table 2. Emulsion copolymerization of 3 with styrene"

\begin{tabular}{|c|c|c|c|c|c|c|c|c|c|}
\hline \multirow{3}{*}{$\begin{array}{l}\text { Exptl. } \\
\text { No }\end{array}$} & \multicolumn{2}{|c|}{ Macromonomer } & \multirow{3}{*}{ Solvent } & \multicolumn{6}{|c|}{ Copolymer } \\
\hline & \multirow{2}{*}{3 or 4} & \multirow{2}{*}{$\begin{array}{c}\text { wt\% } \\
\text { in feed }\end{array}$} & & \multirow{2}{*}{$5^{b)}$} & \multirow{2}{*}{$\begin{array}{l}\text { Yield } \\
(w t \%)\end{array}$} & \multicolumn{2}{|c|}{$\begin{array}{c}\text { Content of } 4 \\
(w t \%)\end{array}$} & \multicolumn{2}{|c|}{$\begin{array}{l}\text { Carboxyl content } \\
\text { (mequiv.) }\end{array}$} \\
\hline & & & & & & $\mathrm{IR}^{\mathrm{c})}$ & Anal. ${ }^{\text {d) }}$ & Calcd.e) & Found? \\
\hline 1 & $\mathbf{3 a}$ & 5.0 & $\mathrm{H}_{2} \mathrm{O}$ & $5 c$ & 90 & 1.4 & & 0 & - \\
\hline 2 & $4 \mathbf{a}$ & 2.4 & $\mathrm{H}_{2} \mathrm{O}$ & $5 \mathbf{a}(2)$ & 26 & 1.5 & & 0.0032 & 0.0064 \\
\hline 3 & $4 a$ & 5.0 & $\mathrm{H}_{2} \mathrm{O}$ & $5 \mathbf{a}$ & 0 & & & & \\
\hline 4 & $4 b-1$ & 1.0 & $\mathrm{H}_{2} \mathrm{O}$ & 5b-1 & 0 & & & & \\
\hline 5 & $4 b-1$ & 1.1 & $0.05 \mathrm{M}$ buffer ${ }^{8)}$ & $5 b-1$ & 0 & & & & \\
\hline 6 & $\mathbf{4 a}$ & 5.0 & $0.05 \mathrm{M}$ buffer & $\mathbf{5 a}$ & 0 & & & & \\
\hline 7 & $4 \mathbf{a}$ & 5.0 & $0.1 \mathrm{M}$ buffer ${ }^{k}$ & $5 a(7)$ & 78 & 4.1 & 3.0 & 0.0076 & 0.011 \\
\hline 8 & $4 \mathbf{b}-1$ & 5.0 & $0.1 \mathrm{M}$ buffer & $5 b-1(8)$ & 95 & 4.9 & 4.4 & 0.017 & 0.024 \\
\hline 9 & $4 b-1$ & 9.4 & $0.1 \mathrm{M}$ buffer & 5b-1 (9) & 68 & 6.1 & 6.0 & 0.022 & 0.023 \\
\hline 10 & $4 b-1$ & 19 & $0.1 \mathrm{M}$ buffer & $5 b-1(10)$ & 26 & 10 & & 0.035 & 0.057 \\
\hline 11 & $4 b-2$ & 5.1 & $0.1 \mathrm{M}$ buffer & $5 b-2$ & 46 & 4.4 & 4.0 & 0.012 & 0.012 \\
\hline
\end{tabular}

a) Containing $2 \mathrm{wt} \%$ of divinylbenzene; initiator (KPS) concentration, $4 \mathrm{wt} \%$ for styrene; at $70^{\circ} \mathrm{C}$ for $9 \mathrm{~h}$.

b) Experimental numbers are shown in parentheses to distinguish one from another.

c) Estimated from the ratio between absorbances of $\nu_{\mathrm{C}=0}\left(\right.$ at $\left.1642 \mathrm{~cm}^{-1}\right)$ and $\delta_{\mathrm{C}=\mathrm{C}, A r}\left(\right.$ at 1944 and $\left.1600 \mathrm{~cm}^{-1}\right)$ in IR spectroscopy.

d) Determined by elemetal analysis of nitrogen.

e) Calculated from the copolymer composition estimated from IR.

n Determined by titration.

8) Containing $0.05 \mathrm{M}$ potassium hydrogen phthalate and $0.0063 \mathrm{M} \mathrm{HCl}(\mathrm{pH} \mathrm{3.6)}$.

b) Containing $0.1 \mathrm{M}$ potassium hydrogen phthalate and $0.0126 \mathrm{M} \mathrm{HCl}(\mathrm{pH} 3.6)$.

ウムを開始剤として用い, $70^{\circ} \mathrm{C}, 9$ 時間の条件で行った。 カルボン酸末端を持たない3はすでに報告されているよ うにスチレン（2 wt\% のジビニルベンゼンを含む）と水 中で容易かつ, 乳化剤なしに乳化重合を起こし, 塩析後 に $90 \mathrm{wt} \%$ の収率で白色ビーズ状の共重合体 5 を与え た ${ }^{12}$. しかし, 4 は 3 よりも乳化力が高く, 蒸留水中で重 合させた場合には4 の仕込み量が增すにつれてェマル ションが安定化し，塩析及び涷結を行っても系は乳化し たままであり, 共重合体を単離することができなかっ

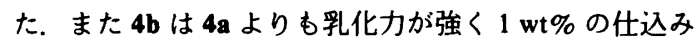
量でも共重合体を単離することができなかった．カルボ ン酸の解離を押え 4 の乳化力を減少させるため重合を $0.05 \mathrm{M}$ フタル酸緩街液 ( $\mathrm{pH}$ 3. 6) 中で行ったがなお不十 分であり, 緩衝液濃度を $0.1 \mathrm{M}$ として塩析の効果を増大 させて初めて乳化共重合に成功した。しかし，4 の仕込 量が多い場合はなお低収率であった。

共重合体 5 中の 4 ユニットの含量は主にIRにおける アミドカルボニルの伸縮振動強度から決定した（Table 2 脚注参照)。これらの值は窒素の元素分析より算出した 値とほぼ一致した。 4 ユニット含量は4の仕込み量より あいずれの場合もいくらか低いものの, 共重合体への 4 の導入率がモノマーの仕込み比から調節可能なことが明
白である．また 5 の表面にあるカルボン酸量を滴定に よって決定したところ、4 ユニットの含量を基準に計算 した値とほぼ一致し、これより4が重合中に乳化剂とし て働いているためポリマービーズの表面に4ユニットが 存在し、ビーズ内部には含まれにくいことが結論され る. すでに小林らは ESCAを用いて3とスチレンとの共 重合体について同様な知見を得ている'列.

このように 5 はポリスチレンの表面に両親媒性のポリ [(アシルイミノ)エチレン]ユニットをスペーサーとして 持ち, さらにその先に反応性のカルボン酸基を有する構 造である. 続いて 5 を酵素の固定化単体として用いてカ タラーゼの固定化を検討した。

\section{3 酳素の固定化}

固定化単体としてはポリ $[(N$-アセチルイミノ)エチレ ン]スペーサーを持つ $5 \mathrm{a}(7)$ 及びポリ [(N-プロパノイル イミノ)エチレン]スペーサーを持つ $5 \mathrm{~b}-1$ (8), 5b-2 を用 い, 水溶性カルボジイミドを縮合㓮として用いて行っ た. 反応は約 $4 \mathrm{mg}$ の牛肝荿カタラーゼ（分子量 242000 , リシン残基数 108） ${ }^{15)}$ を約 $120 \mathrm{mg}$ の上に固定化する条 件に統一して行った。なお䣼素の固定化量はIRにより 固定化酵素中のペプチド基のカルボニル伸縮振動の吸光 度を測定し, 別途 $\mathbf{5}$ とカタラーゼの混合試料から作成し 
Table 3. Immobilization of bovine liver catalase on $5^{3)}$

\begin{tabular}{|c|c|c|c|c|}
\hline $\begin{array}{c}\text { Exptl. } \\
\text { No }\end{array}$ & $\begin{array}{c}\text { Base } \\
\text { copolymer }\end{array}$ & $\begin{array}{l}\mathrm{pH} \text { of } \\
\text { solvent }\end{array}$ & $\begin{array}{c}\text { Catalase } \\
\text { content }^{\text {b) }} \\
(w t \%)\end{array}$ & $\begin{array}{c}\text { Activity } \\
\text { (mmol/min } \\
\text { mg-enzyme) }\end{array}$ \\
\hline 1 & $5 a(7)$ & $4.0^{d)}$ & 1.0 & 2.2 \\
\hline 2 & $5 a(7)$ & $4.6^{c)}$ & 0.76 & 3.3 \\
\hline 3 & $5 \mathbf{a}(7)$ & $7.0^{n}$ & 0 & \\
\hline 4 & $5 b-1(8)$ & 4.0 & 0.75 & 1.0 \\
\hline 5 & $5 b-1(8)$ & 4.6 & 0.72 & 5.9 \\
\hline $6^{8)}$ & $5 b-1(8)$ & 4.6 & 0 & \\
\hline 7 & $5 b-1(8)$ & 7.0 & 0.43 & 3.7 \\
\hline 8 & $5 b-2$ & 4.6 & 0.78 & 4.7 \\
\hline 9 & $5 b-2$ & 7.0 & 0.39 & \\
\hline
\end{tabular}

) Typically, $4 \mathrm{mg}$ of enzyme was treated with $120 \mathrm{mg}$ of 5 and an excess amount of 1-ethyl-3-(3-diethylaminopropyl)carbodiimide hydrochloride at $25^{\circ} \mathrm{C}$ for $13 \mathrm{~h}$.

b) Determined by IR.

c) For the decomposition of $\mathrm{H}_{2} \mathrm{O}_{2}$ in $\mathrm{pH} 7.0$ phosphate buffer at $30^{\circ} \mathrm{C}$

d) $0.05 \mathrm{M}$ Potassium hydrogen phthalate buffer.

c) $0.05 \mathrm{M}$ Potassium hydrogen phthalate $/ \mathrm{HCl}$ buffer.

n $0.05 \mathrm{M}$ Phosphate buffer.

s) Without carbodiimide.

た検量線を基隼に決定した．固定化の結果ならびに得ら れた固定化醭素の触媒活性を Table 3 に示す。

5a (7) の場合, 可溶性の 2 を用いたカタラーゼの化学 修飾には適当であった $\mathrm{pH} 7$ の条件下では固定化は全く 進行せず，溶媒の $\mathrm{pH}$ を 4.6 以下にすることが必要で あった. しかし, 固定化量は最高の Exptl. No. 1 の場合 でも仕込み量の $1 / 3$ 程度と低いものであった. 5b の場 合も溶媒の $\mathrm{pH}$ が低いほど酵素の固定化量は多いが，や はりいずれも低いものであった．また水溶性カルボジィ ミドなしで反応を行った場合 (Exptl. No.6) はIRから 判断する限りでは固定化は全く起こっておらず，䣼素の 固定化が担体のカルボン酸基とカタラーゼ中のリシンの $\varepsilon-了 ミ /$ 基との共有結合によっていることが明白であ る.

このようにして調製した固定化䣼を用いて $30^{\circ} \mathrm{C} に$ おける過酸化水素の分解反応を検討した，カタラーゼを 可溶性の 2 で化学修飾したものは水中に可溶であり, ま
た触媒活性も未修飾のカタラーゼとほぼ等しいのに対し て，今回の固定化醉素の場合カタラーゼ $1 \mathrm{mg}$ 当たりの 活性は未固定のものの $1 / 1000$ 程度の活性しか示さな かった．これは主に䣼素が固定化されているおり，基質 との接触が不利なためと推測している. pH 4.0 で固定化 したものは活性が低く，固定時に一部䣼が失活したも のと考えられる. また当初期待したアシルイミノェチレ ン銷の置換基及び長さの酵素活性に及ぼす影響について は活性が低すぎるため明白ではなかったが, Exptl. No.5 のサンプルが約 $0.3 \mathrm{mM}$ の過酸化水素を含むクロロホル ム中で活性 $(0.45 \mu \mathrm{mol} / \mathrm{min} \cdot \mathrm{mg}$ カタラーゼ)を示したこ とからアシルイミノエチレン鎖が固定化酵素中であカ夕 ラーゼの有機溶媒中での安定性に寄与していることが示 唆された。

\section{文献}

1) M. Miyamoto, K. Naka, M. Tokumidzu, and T. Saegusa, Macromolecules, 22, 1604 (1989).

2) S. Kobayashi, M. Kaku, S. Sawada, and T. Saegusa, Polym. Bull., 13, 447 (1985).

3) S. Kobayashi, E. Masuda, S. Shoda, and Y. Shimano, Macromolecules, 22, 2878 (1989).

4) S. Kobayashi, H. Uyama, N. Higuchi, and T. Saegusa, Macromolecules, 23, 54 (1990).

5) H. Uyama and S. Kobayashi, Macromolecules, 24, 614 (1991).

6) M. Miyamoto, Y. Sano, T. Saegusa, and S. Kobayashi, Eur. Polym. J., 19, 955 (1983).

7) S. Kobayashi, T. Igarashi, Y. Moriuchi, and T. Saegusa, Macromolecules, 19, 535 (1986).

8) S. Kobayashi, H. Uyama, N. Higuchi, and T. Saegusa, Macromolecules, 23, 54 (1990).

9) S. Kobayashi, H. Uyama, D. R. Liu, and T. Saegusa, Macromolecules, 23, 5075 (1990).

10) Y. Chujo, Y. Yoshifuji, K. Sada, and T. Saegusa, Macromolecules, 22, 1074 (1989).

11) Y. Chujo, K. Sada, K. Matsumoto, and T. Saegusa, Macromolecules, 23, 1234 (1990).

12) S. Kobayashi, H. Uyama, and I. Yamamoto, Makromol. Chem., 191, 3115 (1990).

13) S. Kobayashi, H. Uyama, I. Yamamoto, and Y. Matsumoto, Polym. J., 22, 759 (1990).

14) M. Miyamoto, K. Naka, M. Shiozaki, Y. Chujo, and T. Saegusa, Macromolecules, 23, 3201 (1990).

15) W. A. Schroeder, J. R. Shelton, J. B. Shelton, B. Robbertson, and G. Apell, Arch. Biochem. Biophys., 131, 653 (1969). 
Preparation of a-Styrylmethyl- $\omega$-(3-carboxylpropyloxycarbonyl)poly[( $N$-acylimino)ethylene] Macromonomers and Their Applications to the Enzyme Immobilization

Masatoshi MiYamoto*1, Toshio OKadA ${ }^{* 2}$, Kensuke NAKA*3, and Takeo SaEguSA*4

*1 Department of Synthetic Chemistry, Faculty of Engineering, Kyoto University, Present address: Department of Chemical and Biochemical Engineering, Faculty of Engineering, Toyama University (3190 Gofuku, Toyama, 930 Japan)

${ }^{* 2}$ Department of Synthetic Chemistry, Faculty of Engineering, Kyoto University (Yoshida, Sakyo-ku, Kyoto, 606 Japan)

${ }^{*}$ Department of Applied Chemistry, Faculty of Engineering, Kagoshima University (Korimoto, Kagoshima, 890 Japan)

${ }^{*}$ Department of Synthetic Chemistry, Faculty of Engineering, Kyoto University; Present address: KRI International, Inc.

(17 Chudoji-Minami-machi, Shimogyo-ku, Kyoto 600, Japan)

Novel styryl-type macromonomers of $\alpha$-styrylmethyl- $\omega$-(3-carboxylpropyloxycarbonyl)poly [( $N$-acylimino)ethylene] structure (4) were prepared by the cationic ring-opening polymerization of 2-methy-and 2-ethyl-2-oxazolines with chloromethylstyrene as initiator and the subsequent treatment of the resulting living polymer ends with an excess amount of glutaric acid in the presence of 2,6-lutidine. The extents of functionalization of styryl and carboxyl groups were almost unity. The soap-free emulsion copolymerization of 4 with styrene gave polystyrene beads bearing carboxyl functionalities on their surface. These were further utilized for the immobilization of bovine liver catalase.

KEY WORDS Styryl-Type Carboxyl-Terminated Macromonomers / 2-Oxazolines / Chloromethylstyrene / Soap-

Free Emulsion Copolymerization / Bovine Liver Catalase / Immobilized Enzyme /

(Received May 6, 1992: Accepted May 8, 1992)

[Kobunshi Ronbunshu, 49(10), 855-860 (1992)] 